\title{
Hybrid Micro-Hydro Power Generation Development in Endau Rompin National Park Johor, Malaysia
}

\author{
Azli Yusop ${ }^{1, *}$, Izat Yahaya ${ }^{1}$, Ghazali Kadis ${ }^{l}$, Maizul Ishak ${ }^{2}$, Mohd Sufyan Abdullah' ${ }^{2}$, Mohd \\ Fadly Razak², Azmi Sidek, and Ismail Abdul Rahman ${ }^{4}$ \\ ${ }^{1}$ CeDS, Universiti Tun Hussein Onn Malaysia 86400, Batu Pahat, Johor, Malaysia \\ ${ }^{2}$ FTK, Universiti Tun Hussein Onn Malaysia 86400, Batu Pahat, Johor, Malaysia \\ ${ }^{3}$ FKEE, Universiti Tun Hussein Onn Malaysia 86400, Batu Pahat, Johor, Malaysia \\ ${ }^{4}$ FKAAS, Universiti Tun Hussein Onn Malaysia 86400, Batu Pahat, Johor, Malaysia
}

\begin{abstract}
Micro-Hydro electrical power systems are very useful for remote area electrification which does not had supply from the national grid. On the contrary, this area has river streams with high potential for micro-hydro power generation. As such, the UTHM ECO-Hydro Team embarked on a project for erecting a micro-hydro power plant with collaboration with National Education Research Center (NERC), Johor National Park Corporation in Endau Rompin. The existing power generation in this area at present is by using diesel generator gives negative impact on finance and environment in the long run. It supplies power to several including library, offices, open laboratory, chalets and dorms.. At the moment, the micro-hydro system complements the diesel generator, thus becoming a hybrid power generation system.
\end{abstract}

\section{Introduction}

\subsection{Location - NERC, Endau Rompin National Park Johor, Malaysia.}

Endau Rompin lies at the headwaters of Endau River astride the Johor-Pahang border. It covers an area of 870 square $\mathrm{km}$, about one and a half times the size of Singapore Island. It includes parts of the Labis and Endau-Mas forest reserves in Johor and the Lesong Forest reserve in Pahang.

The area contains a unique assemblage of lowland and hill rain forest with pristine rivers and varied wildlife. Besides possessing its own plants found nowhere else in the world, it is also home to the largest population of those highly endangered animals (e.g. Sumatran rhinoceros). This makes the area an important part of Malaysia's natural heritage that is badly in need of conservation. 
The Nature Education and Research Centre (NERC), Endau Rompin became a reality with the collaboration and support of the Johor government, the Danish Corporation Environment and Development (DANCED) and the Malaysian Nature Society (MNS). Funding for the project was provided by DANCED while MNS is the consultant for the implementation of the NERC on behalf of Johor National Park Corporation (PTNJ) [1]. This centre is being developed as a focal point for nature education and research centre for visitors from all over the world.

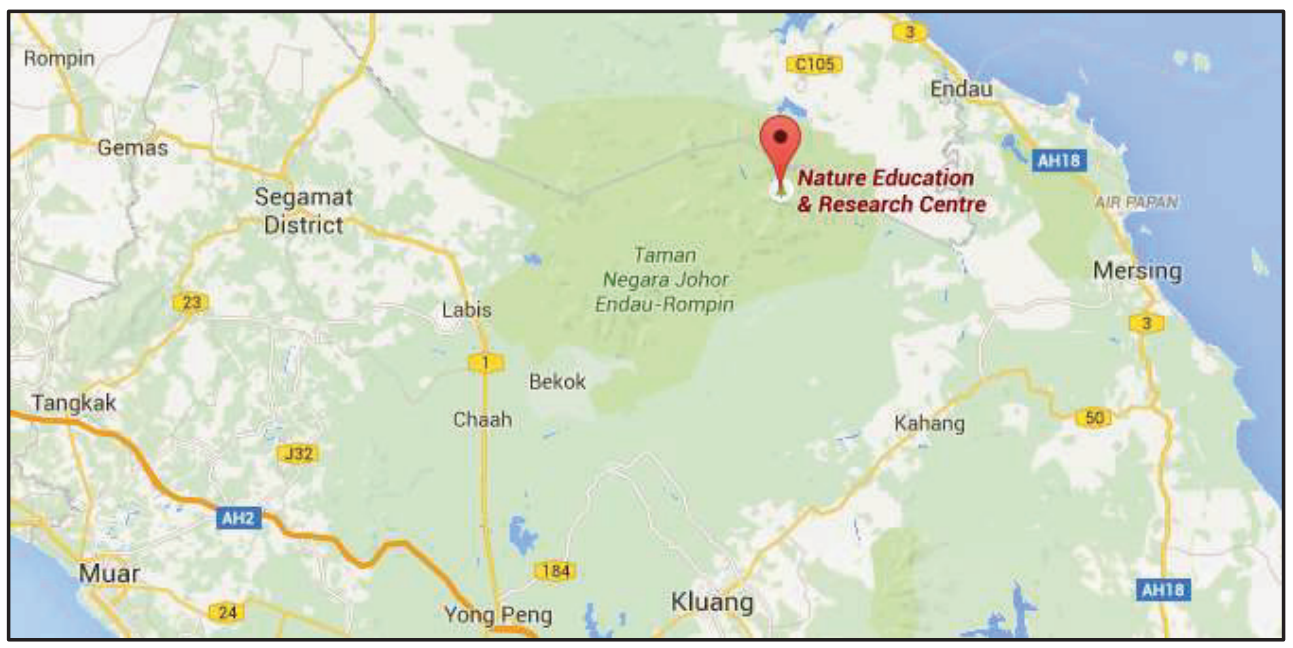

Fig. 1. Location of NERC, National Park Endau Rompin [2].

\subsection{Micro-Hydro}

Flowing and falling water have potential energy. Hydropower comes from converting energy in flowing water by means of a water wheel or through a turbine into useful mechanical power. This power is converted into electricity using an electric generator or is used directly to run milling machines. Small-scale hydropower systems, however, are receiving a great deal of public interest as a promising, renewable source of electrical power for homes, parks and remote communities [4].

A hydro power is generally categorized by six (6) types. The systems are classified as large, medium, small, mini, micro and pico according to their installed power generation capacity. The electrical power is measured in watts (W). General classification of hydro power pants were given in Table 1.

Table 1. A general classification of hydro power plants [5].

\begin{tabular}{|c|c|}
\hline Type & Capacity \\
\hline Large-Hydro & More than 100MW \\
\hline Medium-Hydro & 15 up to $100 \mathrm{MW}$ \\
\hline Small-Hydro & $1 \mathrm{up}$ to $15 \mathrm{MW}$ \\
\hline Mini-Hydro & Above $100 \mathrm{~kW}$, but below $1 \mathrm{MW}$ \\
\hline Micro-Hydro & From $5 \mathrm{~kW}$ up to $100 \mathrm{~kW}$ \\
\hline Pico-Hydro & From few hundred watts up to $5 \mathrm{~kW}$. \\
\hline
\end{tabular}


In this project, the maximum electrical power output was calculated to be $15 \mathrm{~kW}$, hence it was categorized as a Micro-Hydro system with reference to Table 1. This system is ideal for power generation for small community in remote areas and away from the grid.

\section{Planning}

This multidiscipline project was funded by UTHM Contract Research Grants (C036), which combines researchers from three areas of expertise namely civil, mechanical and electrical engineering. On the other hand, this group was also supported by ecologists to study the water quality of Semawak River. Being located in a remote area with the hilly terrain, this project poses a special kind of challenge to the researcher's to develop and install the micro-hydro system with minimal environmental impact.

The development of micro hydro system in NERC began in June 2012 and fully operational in 18 October 2014. Early planning between the researchers and the Johor National Park Corporation was implemented carefully and periodical meetings were conducted to ensure the success of this project. Table 2 presents the timeline of activities that has been implemented.

Table 2. Timeline activities to completing the micro hydro system [6].

\begin{tabular}{|c|l|l|}
\hline No. & Time & Activity \\
\hline 1. & $\begin{array}{l}\text { June }- \text { Dis. } \\
2012\end{array}$ & $\begin{array}{l}\text { Micro hydro fieldwork data acquisition for civil, mechanical, } \\
\text { electrical and ecology (phase 1). }\end{array}$ \\
\hline 2. & $\begin{array}{l}\text { Oct. }- \text { Nov. } \\
2012\end{array}$ & $\begin{array}{l}\text { Preparation of model and prototype for the MOA signing ceremony } \\
\text { on the 19th Convocation UTHM. }\end{array}$ \\
\hline 3. & Nov. 2012 & $\begin{array}{l}\text { MOA signing ceremony between UTHM and Johor National Park } \\
\text { Corporation (PTNJ). }\end{array}$ \\
\hline 4. & $\begin{array}{l}\text { Nov. }- \text { Dis. } \\
2012\end{array}$ & Technical specifications document preparation and workshop. \\
\hline 5. & $\begin{array}{l}\text { Dis. 2012 } \\
\text { Mac } 2013\end{array}$ & $\begin{array}{l}\text { Micro hydro fieldwork data acquisition for civil, mechanical, } \\
\text { electrical and ecology (phase 2). }\end{array}$ \\
\hline 6. & $\begin{array}{l}\text { Jan. }- \text { Feb. } \\
2013\end{array}$ & Purification and final correction of technical specifications. \\
\hline 7. & $\begin{array}{l}\text { Mac }- \text { Mei } \\
2013\end{array}$ & $\begin{array}{l}\text { Preliminary works started (site clearance, surveying contour and } \\
\text { levelling) }\end{array}$ \\
\hline 8. & $\begin{array}{l}\text { Jun }- \text { Sept. } \\
2013\end{array}$ & $\begin{array}{l}\text { Turbine house construction work (soil work, concrete, frame, wall, } \\
\text { ceiling, plastering \& painting). }\end{array}$ \\
\hline 9. & $\begin{array}{l}\text { Sept. }- \text { Oct. } \\
2013\end{array}$ & Clearing pipeline routes from forebay to turbine house. \\
\hline 10 & $\begin{array}{l}\text { Oct. }- \text { Dis. } \\
2013\end{array}$ & Forebay construction. \\
\hline 11. & $\begin{array}{l}\text { Dis. 2013 }- \\
\text { April 2014 }\end{array}$ & $\begin{array}{l}\text { Pipeline system installation (logistic, arrangement, pipe connection, } \\
\text { valve installation, testing) }\end{array}$ \\
\hline 12. & $\begin{array}{l}\text { April }- \\
\text { Jun } 2014\end{array}$ & Turbine generator and electrical systems installation. \\
\hline 13. & $\begin{array}{l}\text { Jun - July } \\
2014\end{array}$ & $\begin{array}{l}\text { Electrical loads installation for UTHM dorm, UTHM open } \\
\text { laboratory \& toilets (underground cable lay, wiring, loads }\end{array}$ \\
\hline
\end{tabular}




\begin{tabular}{|c|l|l|}
\hline & & installation). \\
\hline 14. & $\begin{array}{l}\text { July - Oct. } \\
2014\end{array}$ & Fully test for Micro Hydro system. \\
\hline 15. & $\begin{array}{l}18 \text { Oct. } \\
2014\end{array}$ & $\begin{array}{l}\text { Micro hydro turbine house opening ceremony by Yang Berhormat } \\
\text { Datuk Hj. Ayub Rahmat (Johor state Health and Environment } \\
\text { Executive Councilor). }\end{array}$ \\
\hline
\end{tabular}

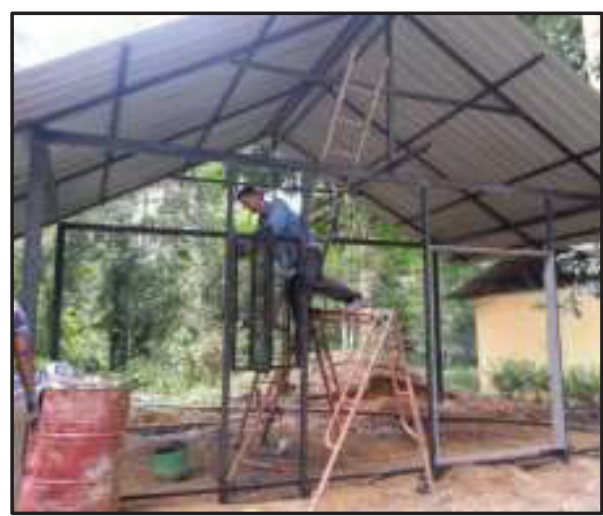

Fig. 2. Turbine house frame construction [3].

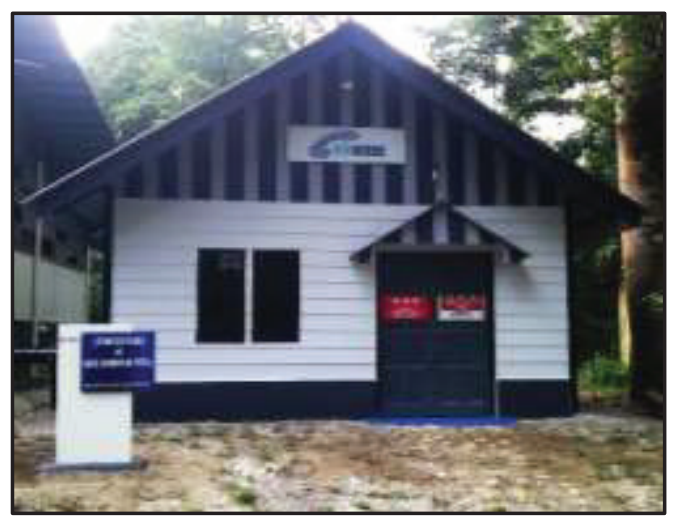

Fig. 3. Turbine house [3].

\section{Design}

This system design takes into account its hilly landscape and plants. Any tree felling should be minimized and must get permission from the authorities. Clearing pipelines routes was done manually without using any heavy machinery that can damage flora or disturb wildlife in the area. The selected forebay has a gross area of 65 meter head with 720 meter downstream distance to the turbine house.

The average flow rate presumably was calculated at $451 / \mathrm{s}$. Catchment area is 6.8 meter $\mathrm{x}$ 5.5 meter x 1 meter. According to the head and flow rate measurement, this micro hydro plant can produce a maximum of $15 \mathrm{~kW}$ using Pelton turbine. In areas with adequate water resources, micro hydro power station is the best option compared with other renewable sources, especially in terms of costing [7].

\subsection{Civil Design}

The system design as shown in Figure 6. The piping size is 10 " and the material is UPVC which can handle pressure up to 10 bar. There are three (3) valves installed, each in forebay area, cross road area and turbine house area. Carbon steel elbow is used as a support for pipes installed every 5 to 10 meters to further strengthen the position of the piping.

Discharge water from the turbine house are channeled into two storage tanks (holding tanks), so it can be used for daily needs. Next the water flows into the existing ecological pond in NERC where there were several species of small fish inside. Finally, after the pond was filled, the water directed into a river that is located downstream near the NERC jetty. The challenge during pipe laying is the bend and steep area as it is in the dangerous condition that can cause a person to slip and fall down. 


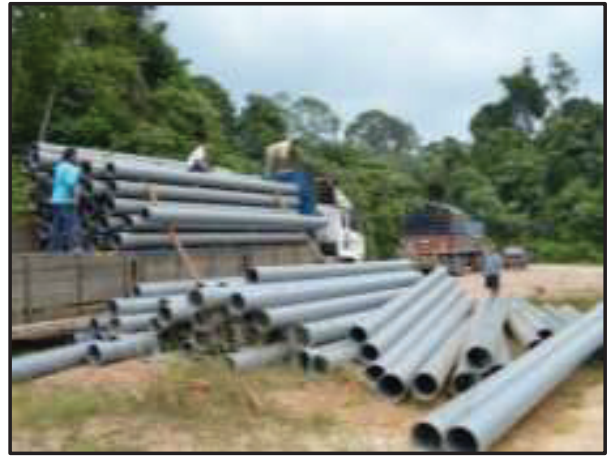

Fig. 4. Piping logistics [3].

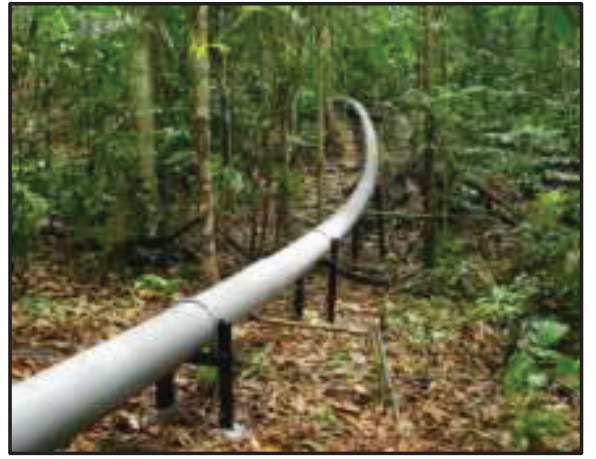

Fig. 5. Pipeline installed [3].

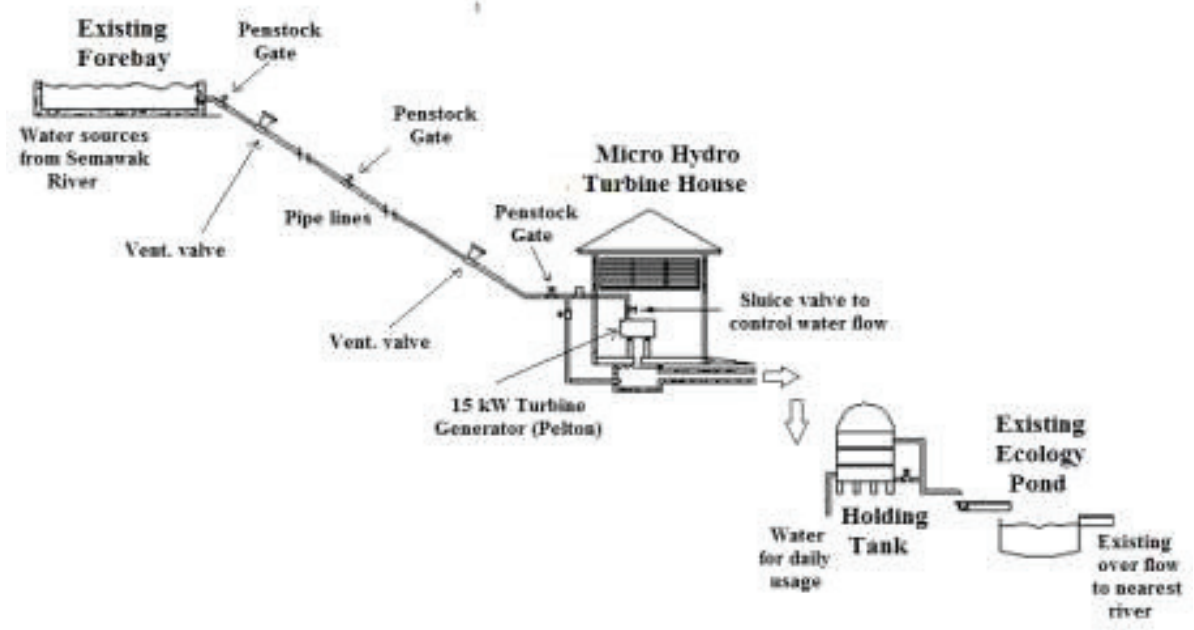

Fig. 6. NERC Micro Hydro system design [8].

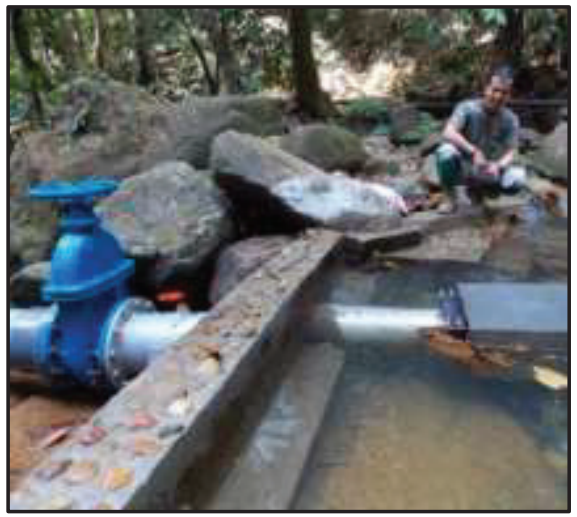

Fig. 7. Forebay area [3].

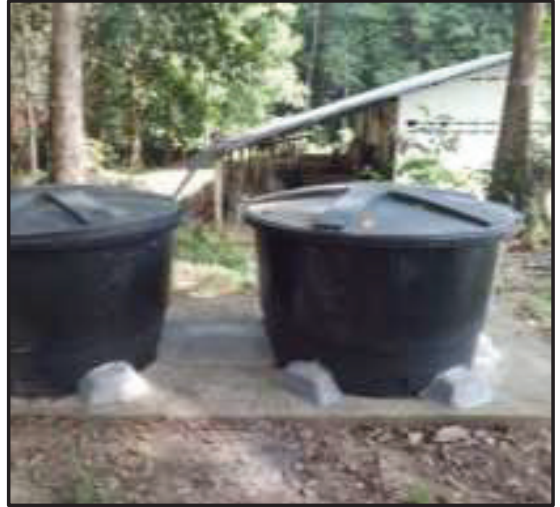

Fig. 8. Holding tanks for daily usage [3]. 


\subsection{Electrical Design}

The electrical system diagram as shown Figure 9. The panelboard had displays such Voltmeter with a selector switch to read the voltage between phases and the line voltage, Ammeter on each phase to measure current, digital frequency meter and digital power meter. The system also being installed with short circuit, over current and earth leakage protective devices.

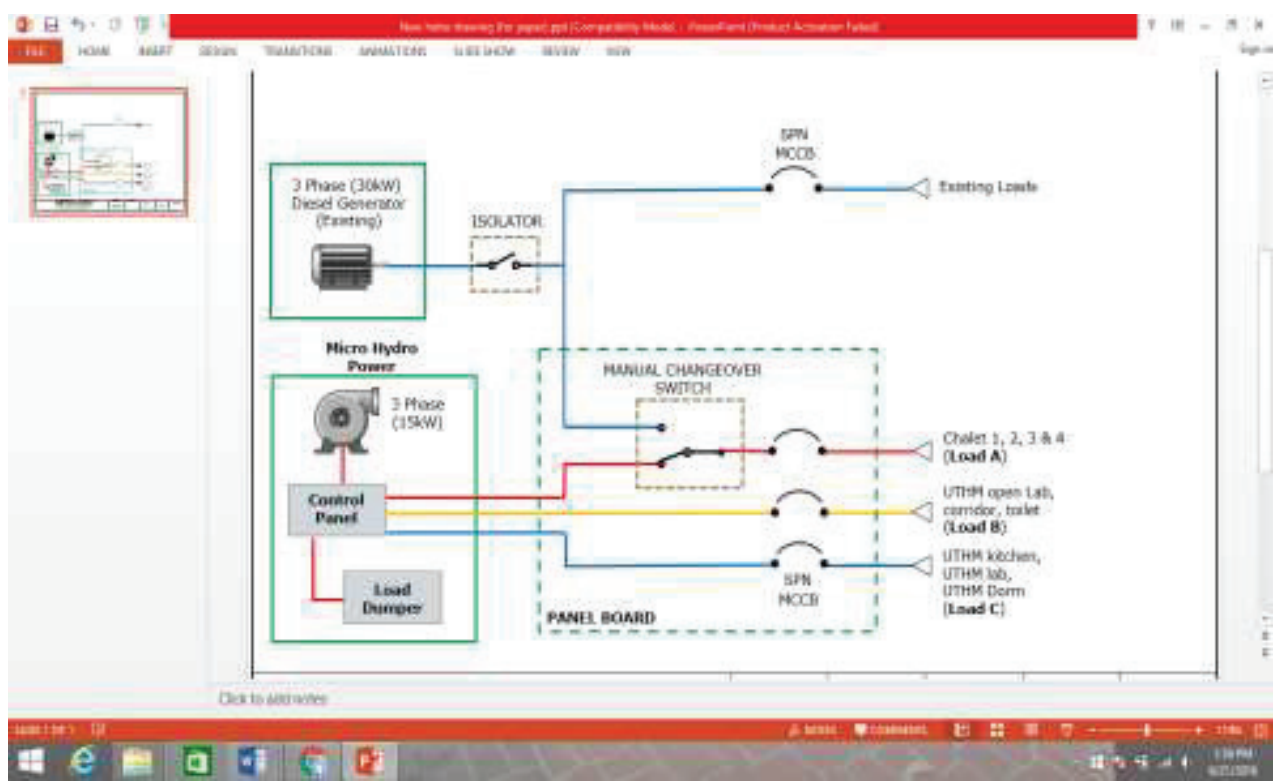

Fig. 9. Electrical system design [8].

The system composed of micro hydro generator, manual changeover switch, storage battery and inverter. The outline of the basic design of the principal equipment and operating system is detailed as following:

\subsubsection{Micro Hydro Generator}

The maximum output power is $15 \mathrm{~kW}$ ( 3 phase), with a voltage of 400/230 volt, $50 \mathrm{~Hz}$ frequency and turbine speed is $1500 \mathrm{rpm}$. The speed of the rotating turbine can be controlled using the intake gate manually depends on the loads current required.

\subsubsection{Manual Changeover Switch}

A manual changeover switch prevents the diesel generator power and the micro hydro power from powering the loads circuit at the same time. It is permanently installed in front of the panel board and operated by onsite personnel. In this project, the chalet loads (chalet $1,2,3 \& 4$ ) is shared by both supply source. At the time when micro hydro does not work, then the diesel generator become a backup supply, and vice versa. 


\subsubsection{Inverter}

The inverter output power is $8 \mathrm{~kW}$, with incoming voltage 240 volt and charging the storage battery at 48 volt. At the time when the battery is fully charged, the inverter will automatically stop.

\subsubsection{Storage Battery}

There is four (4) units of battery (12 volt) installed in series to create a total 48 volt with $120 \mathrm{aH}$ each. The storage capacity was determined to be $5.76 \mathrm{~kW}$. The battery life percentage are shown on the inverter display.

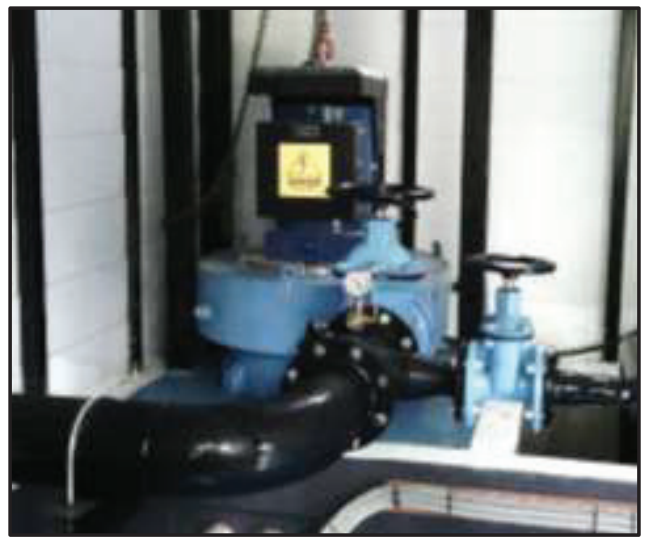

Fig. 10. Micro Hydro turbine installed [3].

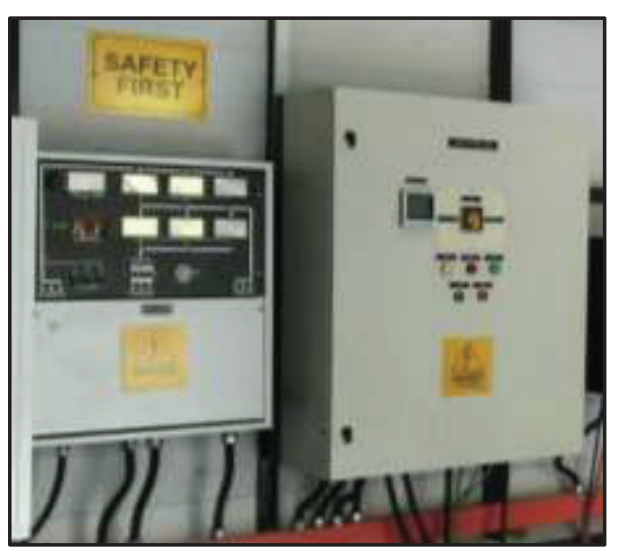

Fig. 11. Micro Hydro panel boards [3].

\subsection{Loads Installation}

Electrical energy from the micro hydro power plant was distributed to three loads (Load A, Load B and Load C). 'Load A' using red phase, is the existing loads which sharing power from diesel generator by using manual changeover switch. It supplies power to Chalet 1 , Chalet 2, Chalet 3 and Chalet 4.

For 'Load B' (yellow phase), were used to supply power to UTHM open lab, corridor and toilets. Cable sizing is $2 \times 6 \mathrm{~mm}$ PVC with armored protection and being laid using underground method. The distance between the turbine house panel board to 'Load B' distribution board (DB) is about 55 meters long.

For 'Load C' (blue phase), was supplying power to UTHM kitchen, UTHM laboratory and UTHM dorm. Cable sizing is $2 \times 10 \mathrm{~mm}$ PVC with armored protection, also being laid underground. The distance between the turbine house panel board to 'Load C' distribution board (DB) is about 250 meters long. Total energy distribution for this system is provided in Table 3. 
Table 3. Total electrical power distribution [6].

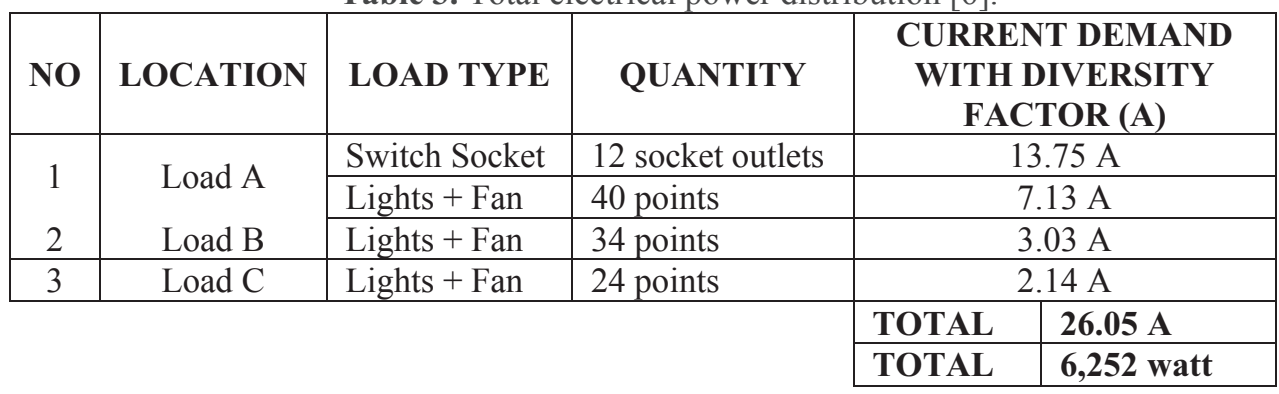

\subsection{Conclusion}

With the success of planning, designing, development and installation of the micro-hydro system the ECO Hydro Team plans to distribute the power supply to other blocks such library, NERC office and another two (2) dorm, as well as a few additional points on the existing loads. The team aims to fully utilize the energy consumption of micro-hydro. The main objective of the development project was achieved as following

i. Improvement in terms of operating time from 12 hours to 24 hours of electricity for domestic use in the NERC.

ii. Improvement of the quality for the ecosystems, environment and surrounding wildlife, including air quality in Endau Rompin National Park (air, water quality and noise level being studied and from time to time the study will continue to be pursued. - This result will be discuss in related papers).

iii. Savings in terms of operating cost, time and maintenance costs compared to diesel operating generator.

Therefore it can be concluded that the use of micro hydroelectric system was timely in the environmental conservation in which it is also upgrading the system in the Endau Rompin National Park.

\section{References}

1. Nature Education and Research Center (NERC) Endau Rompin Natinal Park Malaysia. Available at http://www.tourmalaysia.com.my/endau/nerc.htm.

2. Google maps Malaysia, available at https://www.google.com.my/maps.

3. ECO Hydro Team (authors) picture collections for micro hydro system project (2012 2013).

4. Natural Resources Canada Renewable and Electrical: "Micro-Hydropower Systems: A Buyer's Guide" - ISBN 0-662-35880-5 (2004).

5. D. Singh: "Micro Hydro Power", Resource Assessment Handbook (2009).

6. ECO-Hydro Team (authors) record based on reports, surveys and meeting minutes (2012-2014).

7. K. Kusakana, J.L. Munda, A.A. Jimoh, Economic and Environment Analysis of Micro Hydropower System for Rural Power Supply. In: Proceeding of the $2^{\text {nd }}$ IEEE Power and Energy Conference (2008). 
8. ECO-Hydro Team initial drawing design based on technical documentation and reports (2013). 